\title{
Dakwah Islam Era Globalisasi
}

\author{
Romli \\ Institut Agama Islam Negeri (IAIN) Metro \\ Jl. Ki. Hajar Dewantara 15.A Iringmulyo Kota Metro
}

$\underline{8474 @ g m a i l . c o m}$

\begin{abstract}
ABSTRAK
The progress of science and technology has brought many changes to society, both attitude and behavior thinking, technological advances and knowledge have made humanity more perfect and masterful, managing nature for the benefit and welfare of human life but other dimensions of scientific and technological progress precisely has caused unwanted results or follow-ups.

The basic concept of Islamic preaching in the global era is the importance of Islamic preaching must first be known the importance of da'wah especially by its executors because to achieve a goal must first understand the goals to be achieved, therefore mastery of the importance of Islamic da'wah is very necessary, such as a business or the process carried out was to invite Muslims from all walks of life to improve a better situation, which was in the form of guidance and development, Key Word Islamic da'wah, the Global Era.

In this writing what is meant by, the use of conception is a concept of Islamic da'wah in the face of the era of information globalization especially in determining the elements of Islamic da'wah
\end{abstract}

Key word : Islamic Da'wah, the era of globalization

\section{A. Pendahuluan}

Teknologi komunikasi telah berkembang dengan pesatnya terutama di negara-negara maju, seperti Amerika Serikat, Jepang serta negara-negara lainnya dan telah banyak dimanfaatkan untuk berbagai macam dalam kehidupan ummat manusia. Intraksi yang tercapai antara manusia dengan teknologi satelit. Komputer, camera, telex, telephon, dan sebagainya. Telah berakibat terjadinya perubahan dalam pola dan tata kehidupan manusia modem masa kini. Di Indonesia kemajuan ini semakin kita rasakan, baik secara langsung maupun tidak langsung bahwa teknologi komunikai dan informasi yang baru telah membentuk dan mengubah pola dan tata cara hidup bangsa Indonesia dan juga sebagai salah satu penentu daii peradaban ummat manusia. Perkembangan dan kemajuan teknologi komunkasi dan informasi yang 
menuju kearah globalisasi informasi cenderung berpengaruh langsung terhadap tingkat peradaban manusia. Terbentuknya strata masyarakat agraris, industri dan mansyarakat informasi adalah tidak terlepas dari pengaruh teknologi global tersebut. Seperti kita lihat sekarang ini perkembangan teknologi komunikasi dan informasi pada dekade ini bergerak sangat pesat sekali, dan telah menimbulkan pula dampak, baik dampak positif maupun dampak negatif terhadap tata dan pola hidup masyarakat di Indonesia pada umumnya.

Kita sadar pula bahwa kemajuan pembangunan banyak kenyataan perlu ditopang oleh penerapan ilmu pengetahuan dan teknologi yang tentunya harus dapat disesuaikan dengan nilai-nilai agama, budaya bangsa Indonesia sendiri. Era informasi dan globalisasi harus kita hadapi dengan kepercayaan diri, dengan kualitas sumber daya manusia yang handal serta dengan tajam dan cermat memanfaatkan momentum positifnya dan mengamankan segi negatifnya secara rasional. Namun suatu hal yang pasti, bahwa informasi berfungsi mendorong gerak pembangunan dan mengembangkan motivasi masyarakat lebih kreatif. Dalam kaitan bahwa gloalisasi informasi perlu diantisifasi secara lebih dini dengan kehati-hatian yang lebih rasional. Dampak dari arus informasi dari berbagai negara maju tidak bisa kita bendung lagi.

Kemajuan ilmu pengetahuan dan teknologi, telah membawa banyak perubahan bagi masyarakat, baik dalam cara berfikir, sikap maupun tingkah laku. Dari dimensi yang satu. Kemajuan ilmu pengetahuan dan teknologi memang telah membuat umat manusia lebih sempurna dan menguasai, Mengelolah alam untuk kepentingan dan kesejahteraan hidup mereka. Tetapi dari dimensi lain, kemajuan ilmu pengetahuan dan teknologi itu justru telah menimbulkan hasil-hasil samping atau ikutan yang tidak direncanakan dan tidak di kehendaki.

Dakwah adalah suatu usaha untuk merealisasikan ajaran-ajaran Islam didalam kenyataan hidup sehari-hari baik, bagi kehidupan seseorang, maupun keliidupan masyarakat sebagaikeseluruhan tata keliidupan bersama dalam rangka pembangunan bangsa dan ummat manusia untuk memperoleh ridho Allah SWT. ${ }^{1}$

Dakwah Islam merupakan kewajiban seluruh ummat Islam di dunia, untuk menyerukan, mengajak setiap manusia untuk taat dan patuh kepada ajaranajaran Islam. Seperti dijelaskan dalam firman Allah swt yang berbunyi:

Dan adakanlah diantara kamu segolongan yang menyeru kepada kebajikan, menyeru kepada ma'ruf dan mencegah dari yang merekalah orang-orang yang beruntung. (QS. Ali Imron : 110). ${ }^{2}$

\footnotetext{
${ }^{1}$ Toha Yahya Umara, Ilmu Dakwah, Bulan Bintang, Jakarta, 1980, h. 2

${ }^{2}$ Kementerian Agama Republik Indonesia, Al-Kamal Al-Qur'an Tajwid Warna, Transletirasi Per Kata, Terjemah Per Kata (Jakarta Pusat: Pustaka jaya Ilmu, 2016).
} 
Dakwah Islam merupakan suatu proses yang dilaksanakan oleh baik perorangan maupun secara kelompok. Oleh karena itu, maka dakwah Islam memerlukan suatu konsepsi yang tepat dan baik. Adapun yang menjadi Konsepsi dasar dakwah Islam adalah:

1. Materi Dakwah

2. Metode Dakwah

3. Media Dakwah

4. Obyek Dakwah. ${ }^{3}$

Suatu konsepsi biasanya digunakan dalam setiap awal kegiatan, yang akan diteruskan kebagian perencanaan sehingga sampai pada elementasinya. Jadi Konsepsi merupakan suatu kegiatan yang sangat diperlukan dalam setiap kegiatan manusia, untuk mencapai suatu tujuan, baik secara individu maupun lebih. Dalam pelaksanaan dakwah Islam ini mutlak memerlpkan konsepsi yang sesuai dengan keadaan masyarakat yang akan dihadapi.

Dalam penulisan ini yang dimaksud dengan, penggunaan konsepsi adalah suatu konsep dakwah Islam dalam menghadapi era globalisasi informasi terutama dalam penentuan unsure-unsur dakwah Islam tersebut diatas, hendaknya harus disesuaikan dengan kemajuan dan teknologi serta pembangunan komunikasi dan era informasi, baik dimasa sekarang maupun di masa yang akan dating.

\section{B. Dakwah Islamiyah}

Ditinjau dari segi etimologi dakwah berasal dari bahasa Arab, yang artinya panggilan, ajakan atau seruan. Dalam ilmu tata bahasa Arab, kata dakwah berbentuk sebagai "Isim Mashdar" kata ini berasal dari fi'il (kata kerja), da'ayad'u yang artinya memanggil, mengajak atau menyeru.

Jika dilihat dari segi istilah, banyak sekali pendapat tentang definis dakwah. Seperti dijelaskan oleh Prof. Dr. Noor Chozin Sufri mengatakan bahwa "dakwah sebagai suatu konsep mengandung pengertian sempit dan luas. Dalan pengertian sempit dakwah sering dilakukan hanya sekedar mengajak, menyeru atau memanggil manusia kejalan Islam, atau mempropagandakan Islam kepada siapa saja. Sedangkan dakwah dalam pengertian luas adalah system nilai yang komprehenship, mencakup seluruh kehidupan, ia memberi petunjuk bagi kehidupan manusia dalam semua aspeknya serta menggariskan fomulasi sistimatik yang akurat, sebab system nilai ajaran Islam memberikan solusi berbagai masalah vital dan fundamental, terhadap berbagai tantangan harkat kehidupan manusia".

Selanjutnya beliau menerangkan lebih lanjut sebagai berikut : Dakwah dalam pengertian sempit terbagi dua yaitu dakwah bi al-lisan yaitu menunjukkan kepada cara-cara dalam pengutaraannya dan penyampaian dakwah ; dakwah bi al-kitabah yaitu dakwah dengan tulisan, seperti tulisan-

${ }^{3}$ Samsul Munir, Ilmu Dakwah, (Amzah, Jakarta, 2009), cet-1, h. 13 
tulisan, dalam surat kabar, majalah dan lain-lainnya. Sedangkan dakwah dalam makna luas adalah da'wah bi al-haal yaitu dakwah yang tidak terbatas pada anjuran dan ajakan melalui lisan saja, akan tetapi juga perbuatan nyata yang bentuknya bisa berupa pendidikan, ekonomi, politik, dan lain-lainnya.

Dakwah adalah Setiap usaha atau aktivitas, baik secara lisan maupun tertulis dan lainnya yang bersifat menyeru, mengajak, memanggil manusia lainnya untuk beriman dan mentaati Allah swt sesuai dengan garis-garis aqidah dan syari' at serta akhlak Islamiyah" 4

Sedangkan Islam menurut pengertian yang hakiki dapat diartikan yaitu tunduk dan mengikuti lahir dan bathin secara ikhlas segala sesuatu yang dibawa oleh Nabi Muhammadi SAW selaku Rasul Allah dengan meyakini datangnya, segala sesuatu dari Tuhan Allah Yang Maha Kuasa".

Islam datang sebagai da'wah universal, beriman dari seluruh kitab-kitab dan Rasul, mengajak kepada persatuan dan kesatuan karena Allah Yang Esa. Seperti dijelaskan dalam satu ayat dari surat Asy-Syuara memperlihatkan kita tentang kesatuan seluruh Risalah, dan kesatuan para Rasul, kesatuan agama, kesatuan seluruh tujuan yaitu Tauhid Allah, menegakkan Akhlak, memerangi kehinaan, dan penyelewengan.

Apabila para da'I kehilangan kepercayaan dan keyakinan dengan dakwah, maka hilanglah Kehangatan serta kesanggupan untuk memberi petunjuk kepada orang lain. Karena orang yang tidak memiliki tidak sanggup untuk memberi. Seperti dijelaskan dalam al-Qur'an memberi pelajaran hidup dan menjelaskanbahwa penyakit yang paling susah menimpa para dai adalah : lemah iman dengan Allah dan perpecahan serta perselisihan.

Adapun yang menjadi aktivitas dakwah dilihat sasaran dapat diklasifikasikan kedalam tiga golong yaitu :

1. Mengajak orang yang belum masuk Islam untuk menerima Islam.

2. Amar ma'ruf, perbaikan dan pembangunan masyarakat (ishlah)

3. Nahi munkar.

Adapun yang menjadi tujuan utama dakwah adalah nilai-nilai atau hal akhir yang ingin dicapai tau diperoleh keseluruhan tindakan dakwah. Untuk mencapai tujuan utama dakwah inilah, maka semua konsepsi dari renca dakwah serta tindakan dakwah harus ditujukan dan diarahkan. Yang menjadi tujuan dakwah adalah terwujudnya kebahagian dan kesejahteraan hidup di dunia dan diakhirat yang diridloi Allah SWT.

\section{Materi Dakwah}

Pada garis besarnya sudah jelas bahwa materi dakwah adalah seluruh ajaran Islam secara kaffah tidak dipenggal-penggal atau dipotong-potong. Materi dakwah, tidak lain adalah al-islam yang bersumber dari aI-Qur'an dan hadist sebagai sumber utama yang meliputi:

${ }^{4}$ Asmuni Sukir, Dasar-dasar Strategi Dakwah, (Al-Ikhlas, Surabaya, 1983), h. 17 
1. Masalah keimanan (aqidah)

2. Masalah Keislaman (syari'ah)

3. Maslaha budi pekerti (akhlakul karimah) 5

Departemen Agama RI pusat telah memilah-milah keilmuan Islam dengan lembagi ilmu pengetahuan dalam beberapa kategori dari kelas umum sampai kelas lebih khusus pembagian ini berdasarkan pembagian ilmu pengetahuan oleh Melvil Dewey yang dikembangkan dalam keilmuan Islam, dimana keilmuan Islam itu sendui dapat digunakan dalam materi dakwah bagi juru dakwah yaitu :

1. Islam (umum)

2. Al-Qur'an dan Ilmu yang berkaitan

3. Hadist dan Al-Qur'an, dan Ilmu yang berkaitan

4. Aqaid dan Ilmu Kalam

5. Fiqih

6. Akhlaq dan Tasawuf

7. Sosial dan Budaya Islam

8. Filsafat dan Perkembangan

9. Aliran dan Sekte dalam Islam

10. Sejarah Islam dan Biografi.

Sedangkan menurut R. Agus Toha Kuswata, materi/pesan yang harus disampaikan meliputi:

1. Aqidah Islam, Tauhid, dan keimanan

2. Pembentukan pribadi yang sempurn

3. Pembangunan masyarkat yang adil dan makamur

4. Kesejahteraan di dunia dan di akherat.

Materi yang sangat luas dan lengkap itu sudah tentu memerlukan pemilahan-pemilahan dan membuat perioritas-perioritas, dengan memperhatikan situasi dan kondisi kemasyarakatan, misalnya pendekatan substansial, situasional dan kondisional, kontektual, disamping itu karena pesan-pesan dakwah ini haruslah manusiawi yang diharapkan dapat membuat pengalaman sehari-hari menurut tatanan agama, maka materi dakwah pun harus meningkatkan kemampuan dan akomodasi manusia dalam kehidupannya.

Oleh sebab itu secara teknis dakwah tidak bisa lepaskan dari dua hal pokok yakni : kemampun penerima dakwah dan tingkat berpikirnya, keperluan masyarakat boyek atau atas permintaanya. Ajaran Islam itu dinamis artinya dapat sesuai dengan situasi perkembangan dunia, progresif, dialektis, romantis, dan rasional. Sedangkan menurut Harun Nasution ajaran Islam itu bersifat Universal dan Rasional, maka di dalam penyampaiannya harus dapat menunjukkan kehebatan ajaran Islam kepada masyarakat yang diajak berkomunikasi melalui argumentasi dan keteranga-keterangan yang mudah

${ }^{5}$ Samsul Munir Amin, Ilmu Dakwah, (Amzah, Jakarta), 2009, h. 89 
difahami oleh mereka. Hal ini penting, jangan sampai terjadi sebaliknya, ajaran-ajaran yang rasional - disampaikan secara samar-samar dan tidak menarik.

Pada pokoknya materi yang dikemukakan hendaknya berdasarkan kepada kondisi serta situasi, tidak berarti bahwa materi-materi yang diterangkan kemudian, tidak diperlukan, tetapi lebih dari itu ajaran Islam harus dikemukakan secara bertahap menurut tempat dan propesinya masing-masing. Maka Materi yang disampaikan oleh seorang da'I harus cocok dengan bidang keahliannya. Materi juga harus cocok dengan metoda dan media serta objek dakwahnya. Pada pokoknya

\section{Metode Dakwah}

Secara etimologis, istilah metodologi berasal dari bahasa Yunani, yakni dari kata "metodos" yang berarti cara atau jalan, dan "logos" artinya ilmu. ${ }^{6}$ Sedangkan secara semantic metodologi berarti ilmu pengetahuan yang mempelajari tentang cara-cara atau jalan yang ditempuh untuk mencapai suatu tujuan dengan hasil yang efektif dan efisien. Efektif artinya antara biaya, tenaga dan waktu seimbang, dan efisien artinya sesuatu yang berkenen dengan pencapaian suatu hasil

Sedangkan Prof. DR. Noor Chozin Sufri menjelaskan bahwa metode dakwah artinya cara-cara yang dipergunakan oleh seorang da'I untuk menyampaikan materi dakwah yaitu ,al-Islam atau serentetan kegiatan untuk mencapai tujuan tertentu.

Dengan demikian metodologi dakwah adalah ilmu pengetahuan yang mempelajari cara berdakwah untuk mencapai tujuan dakwah yang efektif dan efisien. Adapun sumber metode dakwah yang dianggap sebagai pedoman dasar atau prinsip penggunaan metode dakwah Islam, sudah termasuk dalam al-Qur'an dan al-hadits Rasulullah saw dalam al-Qur?an prinsip-prinsip dakwah ini disebutkan dalam surat an-Nahl ayat 125 sebagai berikut:

Serulah (manusia) kepada jalan tuhanmu dengan hikmah dan pelajaran yang baik dan bantahlah mereka dengan cara yang baik20

Dari keterangan ayat diatas ada tiga prinsip ajakan kepada agama Tuhanmu (dalam penyampaian dakwah) dengan :

1. Cara yang bijaksana

2. Nasehat yang baik

3. Berdebat dengan cara yang baik

Selain prinsip-prinsip metode dakwah diatas, seorang da'I/'mubligh juga diharapkan memperhatikan pula fakor-faktor yang mempengaruhi pemilihan dan penggunaan surat metode, agar metode yang dipilih dan digunakan benarbenar fungsional, factor-faktor yang dimaksudkan adalah :

1. tujuan dengan berbagai jenis dan fungsinya

${ }^{6}$ Asmuni Sukir, Op.cit, h. 99 
2. Wasasan dakwah dengan segala kebijakan/politik pemerintah, tingkat usia, pendidikan, peradaban (kebudayaan) dan lain sebagainya.

3. Situasi dan kondisi yang beraneka ragam keadaannya

4. Media dan fasilitas (logistik) yang tersedia, dengan berbagai macam kuantitas dan kualitasnya.

5. Kepribadian dan kemampuan seorang da'i/mubaligh ${ }^{22}$

Dari sumber metode itu tumbuh metode-metode yang merupakan operasionalisasinya yaitu dakwah dengan lisan, tulisan, dan bil-hal. Dakwah dengan lisan berupa ceramah, seminar, symposium, diskusi, khutbah, sarasehan, brainstorming dan lain-lain. Dakwah dengan tulisan berupa buku, majalah, surat kabar, spanduk, pamflet, lukisan-lukisan dan lain-lain. Dakwah bil-hal berupa prilaku yang sopan sesuai dengan ajaran al-Islam, memelihara lingkungan, mencari nafkah dengan tekun, ulet, sabar, semangat kerja keras, menolong sesama manusia misalnya mendirikan rumah sakit, mendirikan dan memelihara anak yatim piatu, mendirikan lembaga pendidikan, mendirikan pusat- pusat pencaharian nafkah seperti pabrik, pusat perbelanjaan dan lainlain, meliputi berbagai sektor kehidupan. Seni meliputi seni lukis, seni tari, dan lain- lain. ${ }^{18}$

Dengan demikian ada beberap macam metode dakwah yang dapat dipakai dalam berdakwah:

1. Metode ceramah (Retorika Dakwah)

Yaitu suatu tehnik-atau metode dakwah yang banyak diwarnai oleh ciri-ciri bicara oleh seseorang da'i/mubaligh pada suatu aktivitas dakwah. Ceramah dapat pula bersifat propaganda, kampanye, berpidato, khutbah, dan lain sebagainya.

2. Metode Tanya jawab

Yaitu penyampaian materi dakwah dengan cara mendorong sasarannya (obyek dakwah) untuk menyatakan sesuatu masalah yang dirasakan belum mengerti dan mubaligh/da' inya sebagai penjawab.

3. Debat (Mujadalah)

Debat sebagai metode dakwah pada dasarnya mencari kemenangan, dalam arti menunjukkan kebenaran dan kehebatan Islam. Dengan kata lain debat adalah mempertahankan pendapat dan idiologinya itu diakui kebenaran dan kehebatannya oleh musuh orang lain.

4. Percakapan antar Pribadi (face to face/percakapan bebas)

Yaitu percakapan bebas antar seorang da'I atau mubaligh dengan individuindividu sebagai obyek dakwahnya. Percakapan pribadi bertujuan untuk menggunakan kesempatan yang baik di dalam percakapan atau mengobrol untuk aktivitas dakwah.

Dalam melaksanakan metode individu conference ini seorang mubaligh/da'I hendaknya mempersiapkan dirinya dengan : 
a. mempunyai pengetahuan dan keterampilan tentang sesuatu hal yang erat hubungannya dengan profesinya (dakwah) maupun pengetahuan lain yang erat hubungannya dengan hidup dilingkungannya.

b. Mempunyai pandangan luas. Artinya tidak relatif terbatas daya nalarnya.

c. Memiliki keterampilan memecahkan masalah, baik masalah- masalah yang berkenaan dengan agama, rumah tangga, negara/politik dan sebagainya

d. Mempunyai daya kreativitas yang tinggi.

5. Metode Demontrasi

Yaitu berdakwah dengan cara memperlihatkan suatu contoh baik berupa benda, peristiwa, perbuatan dan sebagainya dapat dinamakan bahwa seorang da'I yang bersangkutan menggunakan metode demonstrasi. Artinya suatu metode dakwah, dimana seorang da'I memperlihatkan sesuatu atau mementaskan sesuatu terhadap sasarannya (massa), dalam rangka mencapai tujuan dakwah yang ia inginkan.

6. Metode dakwah Rasulullah SAW.

Seorang da'I internasional pembawa agama Islam dari Tuhannya (Allah) untuk seluruh Alam. Beliau didalam membawa missi agamanya menggunakan berbagai macam metode antara lain :

a. secara langsung (face to/face)

Artinya langsung beliau berhadapan dengan orang yang di dakwahi, . yaitu:

- Dakwah secara sembunyi-sembunyi

- Dakwah secara terang-terangan

- Politik Pemerintah

- Peperangan.

b. Secara Tidak Langsung

- Yakni dengan membina komunikator perantara artinya sahabat yang telah beliau bina ini menyampaikan da'wah beliau kepada. Orang lain baik sebagai anggota masyarakat biasa ataupun sebagai guru yang khusus ditugaskan untuk itu.

- Surat-menyurat.

7. Pendidikan dan Pengajaran Agama

Pendidikan dan pengajaran agama dapat dijadikan sebagai metode dakwah. Sebab dalam definisi dakwah telah disebutkan bahwa dakwah dapat diartikan dengan dua sifat, yakni bersifat pembinaan (melestarikan dan membina agar tetap beriman) dan pengembangan (sasaran dakwah).

8. Mengunjungi rumah (silaturahmi/home visit)

Yaitu suatu metode dakwah yang dirasa cukup efektif untuk dilaksanakan, dalam rangka mengembangkan maupun membina umat Islam yaitu menggunakan metode dakwah dengan mengunjungi rumah sasaran dakwah. 


\section{E. Media Dakwah}

Arti istilah media bila dilihat dari asal katanya (etimologi), berasal dari bahasa latin yaitu "median" yang berarti alat perantara. Sedangkan kata media merupakan jamak dari pada kata median tersebut. Pengertian semantiknya media berarti segala sesuatu yang dapat dijadikan sebagai alat (perantara) untuk mencapai suatu tujuan tertentu. Dengan demikian media dakwah adalah segala sesuatu yang dapat dipergunakan sebagai alat untuk mencapai tujuan dakwah yang telah ditentukan. Agar dakwah dapat mencapai sukses sesuai tujuan, seorang juru dakwah dalam memilih media harus mempertimbangkan :

1) Tujuan dakwah yang hendak dicapai.

2) Materi dakwah

3) Sasaran dakwah

4) Kemampuan da'I

5) Ketersediaan media

6) kualitas media.

HA W. Widjaja telah membagi media komunikasi kedalam 2 kategoiyaitu :

1. Media Umum

Media umum ialah yang dapat digunakan oleh segala bentuk komunika: contohnya adalah radio $\mathrm{CR}$, OHP dan seterusnya.

2. Media Massa

Media massa adalah media yang digunakan untuk komunikasi massal Disebut demikian karena sifatnya yang massal misalnya : Pers, Radic Film, Televisi, dan Internet.

Dengan demikian media dakwah dapat dirincikan sebagai berikut:

a. Lisan

yakni penyampaian materi yang diucapkan dengan lisan, ucapan misalnya; ceramah, pidato, kuliah, diskusi, seminar, penataran, lokakarya, musyawarah nasehat, obrolan bebas, tabligh, penerangan agama.

b. Tulisan

yakni komunikasi dalam rangka dakwah yang dilakukan dengan perantar; tulisan, baik berupa bentuk surat yang dikirimkan kepada orang tertentu ataupun karangan-karangan di surat kabar, majalah, termasuk juga dalamnya buku-buku bulletin, risalah, pamplet, pengumuman tertulis edaran diktat, spanduk, yang kesemuanya menggunakan kata-kata atau kalimat- kalimat yang ditulis.

c. Lukisan atau gambaran

Ialah media di dalam komunikasi dengan menggunakan perantara seni lukis berupa lukisan, gambaran, peta fistrif yang dapat diproyeksi, foto, grafif diagram, statistik cerita bergambar, dan sebagainya.

d. Audio Visual 
Cara penyampaian sekaligus merangsang indra penglihatan dan pendengaran, misalnya : internet, televisi, film, sandiwara, drama wayang, ketoprak dan sebagainya. Media ini sekaligus bias dilihat dan didengar.

e. Perbuatan

yakni suatu bentuk penyampaian langsung dengan cara mempergunakan atau memperlihatkan perbuatan atau tingkah laku misalnya : melihat orang sakit, klinik bersalin, silaturahmi, membangun masjid dan sebagainya amaliah yang telah diajarkan agama.

f. Organisasi

Yakni bentuk komunikasi di dalam penyampaian dakwah dengan alat suatu organisasi, baik organisasi politik sosial dan lain-lainnya.

\section{F. Tujuan Dakwah Islam}

Dakwah merupakan suatu rangkaian kegiatan atau proses, dalam rangka mencapai suatu tujuan tertentu. Tujuan ini dimaksudkan untuk memberi arah atau doman bagi gerak langka kegiatan dakwah. Sebab tanpa tujuan yang jelas seluruh aktivitas dakwah akan sia-sia. Apabila ditinjau dari konsep-konsep system pendekatan, tujuan dakwah merupakan salah satu unsur dengan yang lainnya saling membantu, mempengaruhi, berhubungan.

Seperti dijelaskan oleh Asmuni Syukir bahwa yang menjadi tujuan dakwah adalah :

1. Tujuan Umum Dakwah

Tujuan umum dakwah merupakan sesuatu yang hendak dicapai dalam aktivitas dakwah. Manusia memiliki akal dan nafsu, akal senantiasa mengajak ke arah jalan kebahagiaan dan sebaliknya nafsu selalu mengajak ke arah yang menyesatkan. Di sinilah dakwah berfungsi memberikan peringatan kepadanya, amar ma'ruf nahi 'anil munkar dan sebagainya agar mereka itu dapat bahagia sejahtera di dunia maupun di akhirat.

2. Tujuan Khusus Dakwah (minor obyective)

Tujuan khusus dakwah merupakan perumusan dari pada tujuan umum dakwah. Tujuan ini dimaksudkan agar dalam pelaksanaan seluruh aktivitas dakwah dapat jelas diketahui kemana arahnya. Oleh karena itu dibawah ini disajikan beberapa tujuan khusus dakwah sebagai terjemahan dari tujuan umum dakwah yaitu :

a. Mengajak ummat manusia yang sudah memeluk agama Islam untuk selalu meningkatkan taqwanya kepada Allah swt. Artinya mereka diharapkan agar senantiasa mengerjakan segala perintah Allah dan selalu mencegah atau meninggalkan perkara yang dilarang-Nya.

b. Membina mental agama (Islam) bagi kaum yang masih mu'alaf. Artinya bagi mereka-mereka yang masih mengkhawatirkan tentang keislaman dan keimanannya (baru beriman).

c. Mengajak ummat manusia yang belum beriman agar beriman kepada Allah (memeluk Agama Islam). 
d. Mendidik dan mengajar anak-anak agar tidak menyimpang dari fitrahnya. Seperti melalui cara menanamkan rasa keagamaan kepada anak, memperkenalakan ajaran-ajaran Islam, melatih untuk menjalankan ajaran-ajaran Islam, membiasakan berakhlak mulia, mengajarkan Al-Qur'an dan sebagainya.

Dengan demikian tujuan dakwah tidaklah terbatas hanya pada cita-cita dan harapan serta do'a kepada Allah tetapi dibarangi dengan aktivitas/kegiatan yang dapat mendorong/memotivasi orang lain untuk merubah sikap, pendapat, prilaku, tindakan dari yang buruk ke yang lebih baik yaitu kejalan Allah.

\section{G. Timbulnya Era Globalisasi}

Era globalisasi informasi, berawal dari gerakan perdagangan bebas global yang didorong oleh persekutuan antara telekomunikasi dan ekonomi yang memungkinkan hubungan antar negara semakin dekat, dengan telekomunikasi menjadikan manusia dapat berbagai kecakapan/dan dokumentasi. Pada tanggal 14 Desember 1988 kabel telephon serat optik yang pertama melintas Atlantik mulai dioperasikan. Kabel baru ini dapat membawa 40.000 sambungan secara serentak, melipat tigakan volume tiga kabel tembaga yang sudah ada ditambah satelit, yang secara bersama dapat membawah seluruhnya 20.000 sambungan.

Kabel serat optik melintasi pasifik mulai dioperasikan dalam bulan april 1989, yang menghubungan Amerika Serikat dan Jepang. Amerika Utara, Eropa, .Asia, dan Australia dihubungkan dengan kabel serat optik. Menjelang tahun1992 lebih dari 16 juta mil serat optik akan terpasang. Ciri era globalisasi informasi menurut Harmoko yaitu ;

1. Tansformasi menuju masyarakat informasi akan terjadi semakin cepat dan semakin meluas. Informasi akan semakin komunitas strategis sehingga siapa yang menguasai informasi dan mampu memanfaatkanya secara daya guna akan semakin maju.

2. Integrasi telekomunikasi dan komputer akan semakin meningkat merupakan kenyataan. Dengan demikian batas antar public network dan priva network akan semakin kabur dan sulit dikontrol. Berbagai jasa baru bermunculan yang semuanya akan memerlukan modus transmisi yang baru.

3. Value added Service (jasa nilai tambah) seperti banking system, system, dan lain-lain akan semakin berkembang disertai dengan masala masalah inter connectivify yang harus dipecahkan tanpa menghilangkan sifat khusus dari system-sistem tersebut.

4. Spektrum pemanfaatan teknologi komunikasi serta optik akan semakin meluas disertai dengan kapasitas yang semakin tinggi dalam kemampu; menyalurkan data, suara dan video sehingga akan ikut mengubah system distribusi penyaluran informasi, serta menciptakan global info higway. 
5. Struktur komunikasi akan semakin multidimensi, lebih berkembang kearah horizontal dan diagonal.

Era globalisasi akan membuat hubungan manusia bertambah luas jangkauannya, dunia semakin sempit, komunitas budaya termasuk budaya pedesaan akan semakin mencair atau bersatu kedalam pengaruh budaya kota. Manusia pada era ini diperkirakan akan muncul kebudayaan massa sebagai arah majunya teknologi, yang khususnya dibidang informasi.

Kalau dilihat kembali pada sejarah perkembangan teknologi komunika massa, maka dapat disimpulkan bahwa proses perkembangan melalui beberaf tahap yaitu :

a. Percepatan reproduksi dalam proses fhotography

b. Penemuan Audio cassette dan video cassette recorder

c. Peningkatan penggunaan telext dan telefoto

d. Pengiriman bahan informasi lewat satelit keseluruh dunia

e. Penguasaan serat optik atu fiber optics yang bebas dari gangguangangguan elektronik, sehingga bias membawa pesan dengan bebas gangguan dan hambatan untuk jarak jauh dengan tingkat akurasi dan kejernihan yang tinggi

Demikian cepatnya perkembangan teknologi informasi dunia, yang menghasilkan dampak positif yang sekaligus negatif bagi perkembangan budaya dan peradaban manusia dan agama, bagi ummat Islam bukan suatu hal yang harus dihindari, akan tetapi harus mencari koasep yang tepat.

\section{H. Informasi Dalam Perubahan Masyarakat}

Menilai tentang pertumbuhan masyarakat informasi yang merupakai proses lebih lanjut dari masyarakat agraris dan masyarakat industri, seperti dijelaskan oleh John Naisbitt, yang menyatakan ada lima hal yang perlu diperhatikan dalam perubahan masyarakat informasi yaitu :

a. Masyarakat informasi merupakan suatu realitas ekonomi.

b. Inovasi dibidang komunikasi dan teknologi komputer, menambah langkah perubahan dalam penyebaran informasi dan percepatar arus informasi.

c. Teknologi informasi yang baru pertama kali diterapkan dalam tugas industri secara bertahap akan melahirkan aktivitas-aktivitas; produk industri yang baru.

d. Setiap individu menginginkan kemampuan menulis dan membaca

e. Keberhasilan atau kegagalan teknologi komunikasi ditentukar oleh prinsip dan sentuhan daya nalar yang tinggi dari masyarakai yang bersangkutan.

Perubahan menuju masyarakat informasi semakin dipercepat oleh penemuan-penemuan teknologi komunikasi. Saluran utama dalam era informasi adalah komunikasi, dimana manusia berintraksi dengan manusia lainnya. Sedangkan pada priode masyarakat agraris, masalahnya adalah 
manusia melawan alam. Demikian pula bagi masyarakat industri, manusia melawan proses hasil pengolahan alam.

Melalui teknologi informasi kita mengenal dua bentuk kenyataan yaitu realitas yang diciptkan Tuhan dan realitas yang diciptakan oleh manusia. Ciptaan manusia disamping mempunyai dampak positif terhadap kehidupan manusia akan tetapi bukan tidak mungkin dapat membuat manusia menjadi mungkar kepada Tuhan.

Sedangkan perubahan-perubahan mendasar akibat kemajuan optik antara lain adalah terjadinya globalisasi, profesionalisasi, materialisasi dan balikan sekularisasi. Manusia semakin percaya pada kemampuannya. Kecenderungakecenderungan ini tentu saja memiliki unsur positif dan negatif.

\section{DAKWAH ISLAM DI ERA GLOBALISASI}

Era globalisasi informasi adalah sebagai konsekwensi dari perkembangan ilmu pengetahuan dan teknologi bukanlah suatu hal harus dihindari. Ummat Islam harus mampu menumbuhkan serta mengembangkan system nilai-nila agama sesuai dengan perkembangan keadaan di era globalisasi informasi.

Dalam proses menghadapi era globalisasi informasi yang sangat penting bagi ummat Islam dan para da'I khususnya adalah mempersiapkan konsepsi dakwah Islam, termasuk didalamnya sikap untuk menyusun suatu konsep dakwah dalam skala nasional. Memperhatikan kemungkinan adanya efek samping yang negatif dari era globalisasi informasi itu, maka diperlukan perhatian dari pada ulama' dan para da'I untuk bersama-sama menggariskan suatu kebijakan melalui dakwah Islam yang terpadu, termasuk penggunaan konsepsi, perencanaan, serta media dakwah, dalam rangka melindungi, melestarikan dan mengembangkan agama Islam.

Konsepsi dasar dakwah slam dalam era globalisasi informasi adalah arti pentingnya dakwah Islam dalam era globalisasi informasi artinya setiap pelaksanaan dakwah Islam dalam era globalisasi terlebih dahulu harus diketahui arti pentingnya dakwah terutama oleh para pelakasanaanya, karena untuk mencapai suatu tujuan harus mengerti dahulu tujuan yang akan dicapai. Oleh karena itu penguasaan arti pentingnya dakwah islam sangat diperlukan, seperti dakwah suatu usaha atau proses yang dilakukan adalah mengajak ummat manusia ke jalan Allah, memperbaiki situasi yang lebih baik, (dakwah yang bersifat pembinaan dan pengembangan). Usaha tersebut dilakukan dalam rangka mencapai tujuan tertentu, yakni hidup bahagia sejahtera di dunia ataupun di akhirat sebagaimana firman Allah dalam surat alBaqarah: 201 yang berbunyi :

"Ya Tuhan kami, berilah kami kebaikan di dunia dan kebaikan di akherat, dan peliharalah kami dari siksa api neraka."

Melaksanakan dakwah dalam arti luas adalah kewajiban yang harus dipikul dan dilaksanakan oleh setiap muslim maupun muslimat. Tidak boleh seorang pun dari kaum muslimin atau musiimah menghindarkan diri dari padanya. 
azas-azas dakwah, dalam penentuan konsepsi dakwah yang didasarkan pada azas filosofis, karena azas ini terutama membicarakan masalah yang erat hubungannya dengan tujuan-tujuan yang hendak dicapai dalam proses atau dalam dalam aktifitas dakwah, azas kemampuan dan keahlian da'I ; azas sosiologis, azas ini membahas masalah yang berkaitan dengan situasi dan kondisi sasaran dakwah ; azas psikologis membahas masalah yang erat hubungannya dengan kewajiban manusia, karena seorang da'I adalah manusia, demikian juga sasaran dakwahnya ; azas efektifitas dan efisiensi, azas ini adalah di dalam aktivitas dakwah harus berusaha mengkesimbangkan antara biaya, waktu maupun tenaga yang dikeluarkan dengan pencapaian hasilnya.

\section{J. Simpulan}

1. Konsepsi dasar dakwah Islam dalam era globalisasi informasi adalah tidak jauh berbeda dengan konsepsi sebelumnya, karena berdakwah adalah menjalankan perintah Allah, yang didalam pelaksanaaiaiya didasarkan pada al-Qur'an dan Hadist serta keadaan masyarakat.

2. Maka yang menjadi konsepsi pada zaman modern ini ialah sebagai berikut: penguasaan dakwah, penguasaan dakwah, dan penguasaan intern dakwah.

3. Penguasaan dakwah ini terdapat juga penguasaan medan luar dan medan dalam. Medan luar adalah orang-orang (kelompok) yang berada diluar jangkauan medan tertentu dari dakwah atau diluar kelompok yang sudah bisa dikatakan terorganisir atau telah terikat dengan peraturan-peraturan Islam. Adapun yang dimaksud dengan medan dalam adalah mereka yang berada didalam suatu kelompok tertentu, telah terorganisir bahkan telah bisa dan akrab.

\section{DAFTAR PUSTAKA}

Asmuni Syukir, Dasar - dasar Strategi Dakwah Islam, Surabaya, Al-Ikhlas,1983

Astrit Susanto, Komunikasi dalam teori dan praktek, Bulan bintang, Jakarta, 1988

Kementerian Agama Republik Indonesia, Al-Kamal Al-Qur'an Tajwid Warna,

Transletirasi Per Kata, Terjemah Per Kata (Jakarta Pusat: Pustaka jaya Ilmu, 2016).

Samsul Munir, Ilmu Dakwah, (Amzah, Jakarta, 2009), cet-1, h. 13

Toto Tasmara, Komunikasi Dakwah,Jakrta,Gaya Media, Pratama,1986

Toha Yahya Umar, Ilmu Dakwah, Wijaya, Jakarta, 1986 